\title{
Legal Assistance by Advocate to Defendant who cannot Afford in Purwokerto
}

\author{
Dessi Perdani Yuris Puspita Sari ${ }^{*}$ \\ 1 Procedure Criminal Law Department, Faculty of Law, Jenderal Soedirman University, 53122, \\ Purwokerto, Indonesia
}

\begin{abstract}
An important requirement that must exist in every legal state is the guarantee of protection of the basic rights of citizenship. Among these basic rights is to get legal assistance services for defendants who cannot afford it for free by an advocate. The law and code of ethics have regulated the provisions relating to the provision of legal aid. The crucial problem lies in the lack of comprehension and comprehensive approach to science through the approach of criminal procedural law in understanding and formulating subsections in several laws so that the image of an advocate is actually seen as a commercial profession and these basic rights are often overlooked. This research is an empirical research using sociological juridical approach. Then, all available data are processed qualitatively and qualitative. This study focuses on the legal assistance conducted by advocates to the incapacitated defendants at the PERADI branch located in Purwokerto. It also explains that a number of factors faced was that they came from their own advocates and from the defendants.
\end{abstract}

\section{Introduction}

Legal assistance is the constitutional right of every citizen to guarantee legal protection and to guarantee the equality before the law. As a means of recognizing human rights that are non-derogable rights, is a right that cannot be reduced and cannot be suspended under any circumstances. Legal assistance is not the mercy given by the State. Rather, it is a human right of every individual and it is the responsibility of the States to protect anyone who can't afford.

Subsection 5 paragraph 1 of Law No. 18 of 2003 concerning Advocates explained "Advocates are law enforcers" called law enforcers who accompany defendants in the trial, not only as objects but subjects with other law enforcers who are equally trying to achieve the fairest decision. In practice, the position of the defendant who can't afford considers that other law enforcers such as the police, prosecutors and judges have understood the law. Therefore, the presence of an advocate is needed to assist the defendant so that the justice process is balanced.

* Corresponding author : dessips.80@gmail.com 
One of the obligations of advocates to the community is to provide legal services to those who are economically disadvantaged (can't afford). Subsection 7 Number 8 of the Code of Ethics Indonesian lawyers say, "Advocates have an obligation to provide legal assistance free of charge (prodeo) for people who cannot afford it.[1]

This is confirmed in Subsection 22 of Law Number 18 of 2003 concerning Advocates which read as follows:[2]

1) Advocates are obliged to provide legal assistance free of charge to justice seekers who cannot afford it.

2) Provisions regarding the requirements and procedures for granting assistance free of charge as referred to in paragraph (1), are further regulated by Government Regulation.

\section{Objective of the study}

This study aims to determine giving legal assistance to the defendant who cannot afford by the advocate at Indonesian Advocates Association/Perhimpunan Advokat Indonesia (PERADI) branch Purwokerto and some obstacles to the implementation.

\section{Methodology}

This type of research is an empirical juridical research, which is a study that uses primary data sources, employing sociological juridical approach. The field research was carried out to obtain primary data. The data is obtained by conducting interviews with respondents and informants. It is done by collecting data that can be accounted for the truth about the problems to be studied. Library research is conducted to obtain secondary data by studying textbooks, legislation, subsections and scientific writing with the aim of obtaining theories and concepts related to the problems to be studied.

\section{Discussion}

\section{1 Giving legal assistance to defendant who can't afford by advocate in PERADI branch Purwokerto}

Legal assistance is the constitutional right of every citizen to guarantee legal protection and guarantee equality before the law. As a means of recognizing human rights that are nonderogable rights, namely a right that cannot be reduced and cannot be suspended under any circumstances. Legal assistance is not the mercy given by the State. Rather it is a human right of every individual and is the responsibility of the State to protect anyone who can't afford.[3]

Providing legal assistance is also known as some form of service, these services are legal aid, legal assistance and legal service. All three has different understandings and forms of implementation. M. Yahya Harahap stated that: [4]

1. Legal aid, which means providing legal services to someone involved in a case or case:

a. Providing legal assistance services is free.

b. Legal assistance in legal aid is more specifically for anyone who can't afford it.

c. The main motivation in the concept of legal aid is to uphold the law by defending the interests and human rights of anyone who can't afford and legally ill.

2. Legal assistance contains a broader understanding of legal aid. In addition to containing the meaning and purpose of providing legal aid services, legal assistance is closer to the 
understanding that we are familiar with the advocate profession, which provides assistance to:

a. Serve good for those who are able to pay for the achievements,

b. Provide assistance to anyone who can't afford for free

3. Legal service, which most people are more likely to give a broad understanding of the concept and meaning of it, is compared to the concept of legal aid and legal assistance purposes, as the legal concepts and ideas contain the meaning and purpose as follows:

a. Providing assistance to the community whose operations are aimed at eliminating discriminatory realities in the enforcement and provision of assistance services between the 'can't afford' and the 'can't afford' with rich people who control the source of funds and financial position.

b. Legal services provided to community members who need it can realize the legal truth by the law enforcers by respecting every community regardless of the rich and the 'can't afford'.

c. Legal services in its operations are more likely to resolve any disputes by adopting a method of peace.

According to Subsection 1 paragraph (1) of Law Number 16 of 2011 concerning Legal Assistance, it is stated that legal assistance is a legal service provided by legal aid providers free of charge to legal aid recipients. Then in Subsection 1 paragraph (2) it is stated that recipients of legal assistance are people or groups of 'can't afford' people. As well as in Subsection 1 paragraph (3) it is stated that legal aid providers are legal aid institutions or community organizations that provide legal assistance services based on this law.[5]

The purpose of implementing legal assistance is stated in Subsection 2 SEMA Number 10 of 2010 concerning Guidelines for Providing Legal Assistance, among others:

1. Relieve the burden of costs that must be borne by members of the 'can't afford' community in court;

2. Providing equal opportunities to the community who can't afford to obtain defense and legal protection when dealing with legal proceedings in court;

3. Increase access to justice;

4. Increase public awareness and knowledge about the law through appreciation, fulfillment and protection of their obligations.

In accordance with PERMA Number 1 of 2014, people who wish to apply for legal assistance in writing to legal aid providers must at least contain:

1. The identity of the Applicant for Legal Aid is evidenced by the identity card and/or other documents issued by the authorized agency

2. A brief description of the subject matter requested for legal assistance

The conditions that need to be attached by the 'can't afford' people who will ask for legal assistance are:

1. A letter of inadequacy (SKTM) issued by the village head / village head of the local area stating that it is true that the person in question is 'can't afford' to pay court fees, or

2. Other Certificate of Social Benefits such as 'Can't afford Family Card' (KKM), Community Health Insurance Card (Jamkesmas), 'Can't afford Rice Card' (Raskin), Family Hope Program Card (PKH), Direct Cash Assistance Card (BLT), Social Protection Card ( KPS), or other documents relating to the list of 'can't afford' people in an integrated government database or issued by other authorities who are authorized to provide information on incapacity.

Applicants who cannot write or are not good at arranging application editors or even illiterate, can submit verbally assisted by an advocate or officer for that and set forth in written form signed by the applicant and advocate or officer at the Advocate Organization or Legal Aid Institution. Requests submitted directly to the advocate must be copied to the relevant Advocate Organization. 
The Legal Aid Provider must check the completeness of the requirements within a maximum of 1 (one) working day after receiving the application for legal assistance. Requests for Legal Assistance have fulfilled the requirements, legal aid providers must submit written readiness or rejection of the application within 3 (three) working days after the application is declared complete. Legal aid providers declare their willingness to provide legal assistance based on a special power of attorney from the recipient of legal aid. Advocates assigned to provide legal assistance free of charge are included in the answer.

The next stage if it has been declared willing, the completed documents are submitted together with the submission of a claim or application in court when registering a case. The application for fee exemption is submitted to the head of the court through the court. The registrar or secretary then checks the eligibility of case fees and budget availability. The results of the examination are submitted to the head of the court as a material for consideration to decide whether the case fee application is granted or rejected. If the request is granted, the head of the court issues a Letter of Determination of Case Fee Exemption Services. If the application is rejected, the litigation process is carried out as usual.

Providing legal assistance by legal aid providers to recipients of legal assistance is given until the legal problem is resolved and / or the case has permanent legal force, as long as the recipient of the legal aid does not revoke a special power of attorney. Moreover, the advocates provide legal services in court, then they also provide services outside the court. In accordance with Government Regulation No. 42 of 2013, the cost of PBH litigation legal assistance activities for one case (criminal, civil, or state administration) until the case has binding legal force is set at Rp. 5,000,000.00 (five million rupiah).

\subsection{The Obstacles in Implementation of Giving Legal Assistance to Defendant who can't afford by Advocate in Peradi Purwokerto}

The factors that become the obstacles faced by Peradi Purwokerto in providing legal assistance to defendants who cannot afford are as follows.[6]

a) Factors of legal substance

The law governing legal aid, one of which is Law Number 16 of 2011 concerning Legal Aid still contains 'can't afford nesses'. In this law, recipients of legal assistance that are only aimed at people or groups of 'can't afford' people, need to be developed again. In addition, it needs to be clarified again about paralegals, lecturers, students of law faculties who in this law are involved in the implementation of legal aid. Arrangements regarding funding in this law also need to be reviewed. The reporting mechanism that must be carried out to get a legal aid budget (funding) also makes it difficult to have to go through verification, accreditation, etc. that go through a long process that is less efficient.

b) Factors of law enforcement

1. Not all Advocates are touched in defending the underprivileged but some of them have also tried to carry out their duties according to the obligations of the profession and consider this part of worship because it helps people with selfless difficulties. They are ready to help 'can't afford' people who are dealing with the law without expecting rewards but must remain professional, not discriminating with other clients.

2. Information and coordination between investigators and other advocates have not been able to work well, so that the appointment of lawyers is uneven and appointed advocates are the same advocates and impressed that.

3. There are also fraudulent behaviors committed by lawyers who have received honoraria from their clients, but the case stopped and is not immediately addressed. The power of attorney that has been given by the client since the initial agreement is used but by ignoring the obligation that should resolve the case handled. 
c) Factors of facilities

The unbalanced number of justice seekers with the advocates. It is an uneven distribution that the spread of lawyers is usually throughout the country and centralized in big cities which results in the 'can't afford' who are mostly in remote villages cannot reach this legal aid.

d) Factors of the community

1. The emergence of individuals who claim to be advocates offering themselves or claiming to be able to solve legal problems. Those who are referred to as case brokers are intermediaries between prospective clients and advocates who will help resolve the case. This situation can be used by them to make more profits.

2. The discovery of falsification of an inadequate certificate which is used as a condition in obtaining free legal assistance.

e) Cultural Factors

In general, it is still difficult for small people to access justice. The existence of a negative side in law is enforcement that haunts the small people. The existence of a culture of doubt and reluctance by the people to come to $\mathrm{PBH}$ is also due to the advocate's image as if they do not want to give assistance if they are not paid or their services in providing legal assistance.

\section{Conclusion}

Legal assistance to defendants who 'can't afford' to do so by Advocates at PERADI Purwokerto has been carried out in accordance with existing procedures as stipulated in PERMA No. 1 of 2014 concerning Guidelines for Providing Legal Aid. Procedures for providing legal assistance are as follows:

1) Submit a written application containing at least the identity of the applicant and a brief description of the subject matter for which Legal Aid is requested.

2) Submit documents relating to the cases.

3) Attach a certificate of 'can't afford' from the Village or officials at the same level as the residence of the Legal

Aid applicant.

4) In the event that the Legal Aid applicant is 'can't afford' to compile a written application, the application can be submitted verbally.

Obstacles in the implementation of legal assistance to defendants who cannot afford by advocates at PERADI Purwokerto are as follows; lack of funding or budget, lack of control and supervision, inefficient mechanisms for legal assistance requests through letters of application for legal assistance addressed to lawyers, administrative mechanisms that do not provide the ease of access to obtain legal assistance to the defendant, the mechanism and the system for obtaining a complicated budget that must go through a long process then it must be passed by $\mathrm{LBH}$, and lack of coordination between investigators and lawyers as well as between the court and the advocates in advocate appointments so that the advocates appoint uneven. While the efforts made in the implementation of providing legal assistance to defendants who are not capable by advocates at PERADI Purwokerto are: allocating funds for the implementation of providing legal assistance to the 'can't afford', increasing the availability of legal aid providers for the 'can't afford' and improving human resources. 


\section{References}

1. Dewan Pimpinan Pusat Kongres Advokat Indonesia (KAI), Kode Etik Advokat Indonesia (Jakarta Selatan, 2013)

2. Act number 18 year 2003 about Advocate

3. F. H. Winarta, Bantuan Hukum: Suatu Hak Asasi Manusia Bukan Belas Kasihan (Elex Media Kompotindo, Jakarta, 2000)

4. M. Y. Harahap, Pembahasan Permasalahan dan Penerapan KUHAP;Penyidikan dan Penuntutan;Edisi kedua (Sinar Grafika, Jakarta, 2007)

5. The explanation of article 1 paragraph (1), (2), and (3) act number 16 year 2011 about Advocate

6. S. Soekanto, Faktor-faktor Yang Mempengaruhi Penegakan Hukum (Grafindo Persada, Jakarta, 2002) 